\title{
Changing Laws in Rape - A positive Drift to Accomplishment in the Legal System of India
}

\section{Suresh Kumar Shetty B*}

Department of Forensic Medicine and Toxicology, Kasturba Medical College, Mangalore, Manipal University, India

\section{Editorial}

"The law of rape is not just a few sentences. It is a whole book, which has clearly demarcated chapters and cannot be read selectively. We cannot read the preamble and suddenly reach the last chapter and claim to have understood and applied it." -Kiran Bedi., Rtd...Joint Commissioner, Special Branch.

As we are advancing towards the 21 st century, we the Indians having accomplished greater pinnacles in the area of technology, aerospace research, academics and also in the field of economics; there is an immense need for the legal system to change and move ahead in a positive direction. The archive acts still prevailing from the British rule even though they have left us, long back! Law needs to be more sympathetic and sensitive towards the victims of this heinous atrocious crime in so that they barely need be reminded of it. Most often the victim is abused and humiliated and that is the regular sight in the present legal scenario.

In the practical setting, few points in the legal act have to be made crystal clear i.e. Sexual intercourse by a man with his own spouse, over 15 years of age, is not considered as a rape! Sexual intercourse in a supervisory situation is deemed to be an offence, even if it is with the consent of the female! As a whole, the process of law is biased against the victim. If the victim is a minor, the onus is on the accused to prove his innocence. But if the victim is a major, it is up to her to prove her charge. Hence this makes the defense worthwhile to prove that the victim is a major. The laws too are biased. This makes even more necessity to take a new look at itself and take affirmative steps to make it a more tough stand against accused and to get judicial absolution. Also, in alleged rape cases, unless the female is medically examined within 24 hours, it becomes practically difficult for the forensic experts to prove that sexual intercourse has occurred or not.

Section 375 of the Indian Penal Code (IPC) defines rape. Rape is an unlawful intercourse done by a man with a woman without her valid consent. In certain cases, when consent is taken by fraudulent means or by misrepresentation, the act is quite rightly- taken as rape! An accused can, for instance put a gun at his victim's head and obtain consent from her. He even can ask his friends to put a gun on her husband's head and inform her that the gun would go off if she did not relent. Consent could also be given fraudulently by giving her intoxicating or stupefying substances.

The other way is by impersonation; an accused may disguise him in the bed of an unsuspecting woman in the dark of night, when the woman, taking him to be her partner not only does not resist, but actively participates in the sexual act. These cases are rare but are not uncommon in the present scenario. Finally the consent of a female of unsound mind and of a girl below 16 are not taken to be lawful consent as it is presumed that they are not in a position to truly understand the nature and gravity of sexual intercourse. The changes made in the existing rape laws since 1983 improved the situation to some extent. The other important things is among is that the punishment for rape was made more severe. Before, the punishment given under Section 376 of the IPC provided only for a maximum sentence of life imprisonment but there was no minimum limit in the section suggested! Thus, hypothetically an accused would have got away with a sentence of just one month. However due to pressure from various organizations, in 1983 the legislature prescribed that the minimum punishment should be an imprisonment of seven years'.

Further, an important part was included in the Section 376(2) - and was added to the existing IPC, like - Rape by a police officer within the jurisdiction premises of a police station; a public servant while taking advantage of his official position; an official in a jail or remand home of an inmate under their custody; anyone on the staff of a hospital against the female bystanders inside the hospital; a pregnant women; a girl under 12 years of age and also about gang rape! The law has prescribed a minimum punishment and to be of a rigorous nature only for ten years in all these cases. However there was difficulty for the alleged victim to prove absence of consent, especially in cases of custodial rape, so a special section was added to the Indian Evidence Act (IEA). According to the new provision under, Section 114A of the IEA - in cases of custodial rape, gang rape and rape of a pregnant woman, if the alleged victim states in the court that she did not consent, then the court shall presume that she did not consent and the burden of proving consent shall shift to the accused (deemed to have not given consent). This was a major changes seen in the present existing legal system.

A administrator of a jail can offer better living conditions to a woman prisoner under custody, if she "willingly "submits to him and such cases will not amount to rape; nevertheless they do signify abuse of official position. In such cases four special provisions are made under $376 \mathrm{~A}, 376 \mathrm{~B}, 376 \mathrm{C}$ and $376 \mathrm{D}$ - were added to the IPC which awards a punishment of five years' imprisonment provided, that the person in authority had sexual intercourse with women in his custody, he will firstly have to prove that the women in question had given consent. If he is unable to do then he will be guilty of custodial rape and shall have to undergo a minimum rigorous imprisonment of ten years. If he is able to prove that the women did consent, he may not be charged with custodial rape but he can be imprisoned for five years under above sections $376 \mathrm{~B}, 376 \mathrm{C}$ and $376 \mathrm{D}$ of IPC.

This revolution has made enough changes in the rape laws to bring it on par with that of the Western legal system in dealing such heinous

*Corresponding author: Suresh KSB, Professor and Head, Office of State Medico-legal Consultant, Department of Forensic, Medicine and Toxicology, Kasturba medical College, Manipal University, Mangalore, India, Tel: 820 2922323; E-mail: sureshbshetty.2009@rediffmail.com

Received May 15, 2014; Accepted May 22, 2015; Published May 24, 2015

Citation: Shetty BSK (2015) Changing Laws in Rape - A positive Drift to Accomplishment in the Legal System of India. Review Pub Administration Manag 3: e102. doi:10.4172/2315-7844.1000e102

Copyright: (c) 2015 Shetty BSK. This is an open-access article distributed under the terms of the Creative Commons Attribution License, which permits unrestricted use, distribution, and reproduction in any medium, provided the original author and source are credited. 
crimes. However, there are still some glaring and obvious deficiencies, such as no separate and speedy trials for heinous crimes such as child rape. The very 'definition of rape' too is set frightening for sexual intercourse to amount to rape; 'penile penetration must be proved. One can overpower women equally or much more violently by thrusting an iron rod into her private parts'. Still such man would not be held guilty of rape!

The parody of legal stand is due to unrelenting existence of a Section 155(4) of the IEA, which gives a scope for a man is prosecuted for rape and if the woman in question is of immoral character then her evidentiary value will not be taken into account! This is because that there is a provision for the accused may false allegations against the women whose character is suspected. Nevertheless consider Section 54 of the same Act that the fact that the accused person is of a bad character is irrelevant.

In fact, it can be argued that these validations are unconstitutional as they infringe the equality clause under the Indian Constitution of Article 14. That becomes extremely unfair to apply different principles to the accused and the complainant only in rape cases? In the present circumstances when offences against women are on the rise- the young girls are raped by auto drivers, professional, by presidential guards in broad daylight, the definition of rape to be of any deterrence- falls extremely inadequate. The one major obstacle in delivering justice in rape cases is the poor quality of investigations both medically and legally in such cases of heinous crime.

The other reasons, behind these ranges from gender prejudice and corruption and to the general inefficiency of the police. In many cases, the police have even refused to lodge the FIR or have lodged an incomplete FIR. The victims are not taken for the prompt medical examination, because in cases of rape, or attempt to rape- medical examination of the victim and of the accused soon after the incident often yields a treasure of corroborative evidence and therefore, such an opportunity should not be lost by the investigating authority. The irony is the manner in which some courts have interpreted the law or assessed the evidence has often proved to be an obstacle in the case also. In spite, of the highest court of the law of land; Supreme Court judgments to the contrary, lower court judges still insist on evidence of physical resistance or marks of injuries or else it will not considers that the woman has not consented. A woman's evidence without corroboration is not considered sufficient in such cases. Therefore the laws pertaining to rape has come to great deterrence and it needs a cooperative victim, professional investigation, diligent prosecution; and a prompt trial or else it shall not be the law, which fail in delivering justice to the victim.

Failure in delivering justice will reflects the failure of the society to protect and serve humanity. Eventually, the courts and the legislature have to make many changes if the laws of rape are to be made strong; where the accused is resourceful or influential- may even compensate by paying huge amounts of money does not get acquitted soon. The courts have to comprehend the fact that these conscienceless criminals- who resort to torture their victims- who even may include small children, are not deterred or controlled by such a small time of imprisonment. Therefore, in the best interest of justice and the society, these criminals should be sentenced to life imprisonment. This view is made in reality recently; when the President of India Pranav Mukherjee has given his agreement to the anti-rape bill which strengths and provides stringent punishments in the prevailing laws in rape, i.e. For life term and even death sentence for rape convicts besides for offences like acid attacks, stalking and voyeurism it delivers even stern punishment. Mukherjee permitted his agreement to the Criminal Law (Amendment) Bill-2013, which was a result of public outrage brought against the background of the country-wide violence over Delhi gang rape, called the Criminal Law (Amendment) Act, 2013.

The law was delivered by Lokh Sabha on March 19 and then by Rajya Sabha on March 21, 2013 has completely swapped an Ordinance circulated on February 3, 2013. This law made various sections of the Indian Penal Code, the Code of Criminal Procedure, the Indian Evidence Act and the Protection of Children from Sexual Offences Act to be amended. The revised law states that an offender can be sentenced to rigorous imprisonment for a term which shall not be less than 20 years, but which may extend to life, meaning imprisonment for the rest of the criminal's life and with a fine, has also made provisions for giving out death sentence to offenders who may have been convicted for such crimes earlier. This also defines stalking and voyeurism as non-bailable offences when repeated by the offenders for a second time. Perpetrators of acid attack will be punished with a 10 -year jail. The law has fixed minimal age to give consent for sex at 18 years of age. In medical setups the law also informs all hospitals should immediately offer first aid and/ or the health treatment should be made free of cost to the victims of acid attack or rape, and on failure to do so is punishable by law. The law also makes provisions for a minimum imprisonment of seven years which may extend to imprisonment for life and a fine for a convict if he is found to be a personal who is a custodian of that place like a police officer, public servant, armed forces personnel or management or hospital staff. The law as per Indian Evidence Act also pursues to amend and allow a rape victim to record her declaration before a judicial magistrate with the assistance of an interpreter or a special educator, if she is temporarily or permanently mentally or physically disabled. The law also makes provisions to video-graph the entire proceedings. At last, if they consciously have realized their mistake and wish to return to society, the Court and investigatory authorities may leave such men on parole; but only after serving a minimum number of years as sentence executed on them.

It is almost clear from all views that the sexual offences are to be disconnected, but if death sentence is given to such convicts it sets a guideline and also a strong message to deter others and with this considerably lowers the graphical representation in the rape cases. This in addition with the good medical, social, legal, investigatory efforts with the prime evidence in the form of victim should come upfront and change the main system of the Indian Penal Code and the legislature. Studying the laws, the process, the application of those laws, and one thing is certain-the entire structure of justice has to change for the betterment of the society. 